\title{
MJN A STUDY ON THE IMPLEMENTATION OF 'RELACTOR' NURSING DELEGATION MODEL BY DELEGATED NURSE at SEMARANG
}

\author{
Vivi Yosafianti Pohan ${ }^{1 *}$, Dewi Gayatri², Eni Hidayati' ${ }^{1}$, Hidayah Risma \\ ${ }^{1}$ Faculty of Nursing and Health, University of Muhammadiyah Semarang, Indonesia \\ ${ }^{2}$ Faculty of Nursing Universitas Indonesia, Indonesia \\ ${ }^{3}$ Bachelor Program of Nursing, University of Muhammadiyah Semarang, Indonesia \\ *Corresponding Author's Email:vivi_yosaf@yahoo.com
}

\begin{abstract}
Background: Leader nurses and nurses are the acceptors of a nursing delegation from the chief nurse as a form of nursing management through nursing delegation. The 'Relactor' Nursing Delegation Model ( $\left.M D K^{\prime} R^{\prime}\right)$ is one of the nursing delegation models in nursing management. Objective: The study was aimed to find out the implementation of $M D K^{\prime} R^{\prime}$ by the delegated nurse in some components including responsibility, accountability, and authority at Semarang's hospital. Method: It was a descriptive quantitative study. The instrument used was a set of questionnaires which passed the validity and reliability test with $\mathrm{r}$ calculate $>r$ table. The subject of the study was 73 nursing delegation acceptors consisting of 11 male nurses and 62 female nurses. The study was conducted at 3 inpatient wards of a hospital in Semarang. Result: The study found that the implementation of $M D K^{\prime} R^{\prime}$ by the of the three components; responsibility, accountability, and authority showed that the implemented responsibility was good enough with $67.1 \%$, the implementation of accountability was good with $89 \%$, and the implementation of authority was good with $47.9 \%$. Conclusion: This study showed that the implementation of $M D K^{\prime} R^{\prime}$ by the nurses accepting nursing delegation in terms of responsibility, accountability, and authority was scored as good.
\end{abstract}

Keywords: $M D K^{\prime} R^{\prime}$, Implementation of $M D K^{\prime} R^{\prime}, M D K^{\prime} R^{\prime}$ accepting nurse

\section{INTRODUCTION}

A nurse is a person who after completing nursing education, works according to the achieved competence, holds special role, function, and responsibility. The nurse who works within a health care institution will be automatically included in the existed management system. It is a nursing management system that includes nursing care activity management. The nursing care is a set of activities done by the nurse to improve patients' health and meet the target of Indonesia Sehat 2025. The nursing care involves analysis, planning, nursing intervention, also the evaluation of the nursing intervention. The nursing care also includes a nursing delegation from the chief nurse to the leader nurse and other nurses. The delegation is a regular activity done in nursing care management (Marquis \& Huston, 2012).

The 'Relactor' nursing delegation model / MDK'R' which was applied at Roemani Hospital of Semarang is one of the delegation models which was proven to be effective and qualified to perform nursing service.
MDK' $R$ ' is a model that effectively helps the chief nurse in conducting management function activity (Pohan, 2017).

Research on 2015 in Aisyah Hospital of Malang found that there was a significant influence between nurse's knowledge and behavior toward the quality of nurse attitude during the nursing delegation at $59 \%$ and $41 \%$. It was also affected by other factors outside the research limitation. Nursing delegation defined as the act as, to give one's task or responsibility to another person or group to complete the objectives of an organization (Marquis \& Huston, 2012; Risal, 2015).

The nursing delegation is an absolute effort that should be implemented by the chief nurse on the team leader when he or she is engaged in another work and is forced to leave the workplace. The delegation enables health personnel to work effectively and efficiently. A system in the hospital gives authority to one of the nurses to lead a unit and the one who is given the authority is called the chief nurse. The chief nurse usually divides 
their members and chooses some team leaders to perform effective nursing care. The leader nurses divide the nursing job for the members which are also called nurses who are also the acceptor of the nursing delegation. Nurses will also report the implementation of the delegation directly to the chief nurse (Swansburg, 2009; Pohan, 2016).

Several previous study at one of the hospitals in Central Java which implemented socialization about 'Relactor' Nursing Delegation Model (MDK'R') showed that the process of execution standards to implement nursing delegation did not exist yet. The result of an interview with the nurse showed that the nursing delegation given by the chief nurse and team leaders was not properly documented. It meant that the implementation of nursing delegation did not meet the responsibility component. The delegation was not properly documented for some reasons such as the incidental occasion that require the delegation giver to leave the workplace, or the delegation process which was agreed through the telephone line instead of face to face delegation. When the delegation acceptor, recognized the delegation, it was properly noted and confirmed to reflect the the accountability. The nurse also mentioned that $M D K^{\prime} R^{\prime}$ had been implemented by some other nurses (authority). It showed that the $M D K^{\prime} R$ ' had not been optimally implemented by viewing the related components, such as responsibility, accountability, and authority (Pohan, 2016).

The objective of the study was to find the representation of 'Relactor' Nursing Delegation Model (MDK'R') implementation on nurses and describe the representation of responsibility, accountability, and authority.

\section{METHODOLOGY}

It was a descriptive quantitative study with a survey design. The population in this study was the delegation acceptor nurse. The sample in this study was 73 respondents taken using the probability cluster random sampling technique. The research was conducted in one of the hospitals in Central Java for 6 months and had gone through ethical clearance. The data was collected through questionnaires consisting of 40 closed questions taking into account responsibility, accountability, and authority component which was developed from the previous questionnaire (Kærnested \& Bragadóttir, 2012). The instrument was tested using the corrected item-total correlation validity test of which $r$ calculate $>r$ table, with score 0.444 and 5\% two-tailed significance.
The Alpha Cornbach reliability test was used and stated as reliable if the reliability coefficient $>0.6$. the validity and reliability test were done using SPSS and was applied to 20 respondents. The research ethics used for this study was to inform consent, confidentiality, anonymous, justice, and beneficial value.

\section{RESULTS}

\section{Validity and reliability test result}

The validity analysis found that the coefficient was higher than the $r$ table $(0.444)$ so that the test items were considered to be valid. The coefficient from the reliability analysis was more than 6 and positive. Therefore, it was considered to be reliable.

\section{Respondent characteristics}

The respondents of this study were 73 nurses accepting MDK'R'. The respondents were 11 (15.1\%) male nurses and $62(84.9 \%)$ female respondents. The education background of the respondents was diploma in nursing ( $2.7 \%$ or two persons) and a professional nurse ( $15.1 \%$ or 11 persons). $65.7 \%$ of the nurses had been working less than 10 years, $23.3 \%$ had been working for $11-20$ years, and $11 \%$ more than 20 years.

\section{Univariate analysis}

Table 1: The Implementation of Responsibility in Nursing Delegation during $2019(n=73)$

\begin{tabular}{|c|c|c|}
\hline Responsibility & $\mathbf{n}$ & $\mathbf{\%}$ \\
\hline Good & 24 & 32.9 \\
\hline Adequate & 49 & 67.1 \\
\hline Total & 73 & 100 \\
\hline
\end{tabular}

The implementation of the delegation model in terms of responsibility showed a good score of 32.9\% (24 respondents) and an adequate score of $67.1 \%$ (49 respondents).

Table 2: The Implementation of Accountability in Nursing Delegation during $2019(n=73)$

\begin{tabular}{|c|c|c|}
\hline Accountability & $\mathbf{n}$ & $\mathbf{\%}$ \\
\hline Good & 65 & 89 \\
\hline Adequate & 8 & 11 \\
\hline Total & 73 & 100 \\
\hline
\end{tabular}

The implementation of the delegation model in terms of accountability showed a good score of $89 \%$ (65 respondents) and an adequate score of $11 \%$ (8 respondents). 
Table 3: The implementation of authority in Nursing Delegation during $2019(n=73)$

\begin{tabular}{|c|c|c|}
\hline Authority & $\mathbf{n}$ & $\mathbf{\%}$ \\
\hline Good & 35 & 47.9 \\
\hline Adequate & 33 & 45.2 \\
\hline Inadequate & 5 & 6.8 \\
\hline Total & 73 & 100 \\
\hline
\end{tabular}

The implementation of the delegation model in terms of authority showed a good score at $47.9 \%$ (35 respondents), adequate at $45.2 \%$ (33 respondents) and inadequate $6.8 \%$ ( 5 respondents).

\section{DISCUSSION}

The responsibility in implementing the nursing delegation model was represented by giving nursing care, improved knowledge, and improved selfprofessionalism. The delegation acceptor should implement the delegation well, based on the defined procedure. The nurse can also improve the responsibility by completing the delegated task in time, based on the operational procedure standard. They must also make plans to minimize the probability of error. The responsibility during the delegation process could be proven through documentation with legal value. Research by Zulkarnain (2017) showed that there is correlation between sub variable nursing delegation function with the nurse performance in implementing nursing care. The finding of the research showed that adequate responsibility is necessary in implementing nursing delegation which also represents nurses' good performance. Responsibility means giving nursing care and improving self-professionalism through the nursing delegation process.

The responsibility of a chief nurse in running the management of the inpatient unit is very important. A study specifically stated that most of the chief nurse's time is consumed by the nursing management function. Nursing delegation is very important to make sure that nursing management runs well. The chief nurse should be able to optimally reach the objective through the assistance of other nurses. Therefore, the nursing delegation from chief nurse to leader nurse is a very important step to reach the objective in managing nursing care (Monteiro \& Simbolon, 2014).

The delegation may succeed through proper time allotment and planning. The planned delegation enables the delegation acceptor to prepare themselves. The accepted delegations are in the form of accountability, authority, and responsibility. The accountability delegation is the delegation of task, in this case, is the chief nurse's task. One of the chief nurse's task is to arrange a working schedule of which it can be delegated to the team leader or leader nurse (Swansburg, 2009).

The other task that should be done by the chief nurse is putting together patient recording, office supply, attending a regular meeting, also delegate nursing tasks related to the patients to the nurse. The success delegation represents the responsibility of the chief nurse in implementing the nursing management function (Habe, 2008). Research showed that nurses' perception of the successful implementation of the nursing delegation was brought better work satisfaction for the nurses (Wahyuningsih \& Yusiana, 2016).

The accountability during the nursing delegation can be proven by showing documents such as the certificate from formal education in undergraduate, graduate, or professional program, also some other documents such as training certificate, added with written or spoken document or journal about the delegation process. The accountability should be possessed by the delegation acceptor to avoid serious errors during nursing care. In developing accountability, the nurse should continually train their skill and ability while giving nursing care. Accountability can also be measured through the nurse's attitude before and after the nursing delegation training. Prawesti et al., (2017) in her research showed the significant difference between attitude value and behavior control before and after the nursing delegation training, yet there was no difference in the subjective norm value before and after the training. The nurse's accountability during the nursing delegation is also supported by the chief nurse's directing function. The chief nurse's workload sometimes limits the ability to give proper direction on the nursing delegation.

Hidayat, Hariyati \& Muhaerawati (2019) stated that there were some other additional tasks for a chief nurse that limit the chief nurse to give optimum direction about the nursing delegation. Tampubolon (2004) concluded that the delegation to the less capable personnel may result in the less optimal implementation of the delegated task and authority. Meanwhile, the procedure of the delegation starts by choosing the candidate for the delegation through background checking which involves educational background, work span, attitude, and ability. It shows that accountability in delegation is mainly affected by the educational background.

The implementation of authority during the nursing 
delegation was found to be inadequate, as the less optimum authority applied by the nurse during the delegation process. It is represented by the less optimal implementation of reward and punishment during the nursing care implementation. A reward was not fully given, even though the nurse completes the delegation properly, and punishment was not also applied when the nurse did not complete the nursing delegation. The implemented authority functions when the nurse gave a delegation letter. Meanwhile, the punishment and reward giving were fully the chief nurse's authority and responsibility. Research by Rodhah, Nildawati \& Rezky (2017) concluded that the nurses' performance at the inpatient unit of RSUD Syekh Yusuf Gowa was influenced by the role of the chief nurse. Chief nurse needed to defend and improve their role as the chief of the unit so that the nursing care could be well presented according to the existed SOP or operational procedure standard, including nursing delegation model.

The authority of the nurse during the implementation of duties need strong motivation from the chief nurse as the one who delegates the task. It is also supported by research from Parmin, (2010) which showed a significant correlation between organization management function from the chief nurse with the nurse motivation. The organizing function can also be applied during a nursing delegation to improve nurse's motivation during the implementation. On the other hand, Ovari (2017) showed the correlation between the implementation of organizing function by the chief nurse with the nurse's job satisfaction were based on the nurse's perception. It scored $p=0.037 ; \alpha=0.05$ with the dominant variable being task delegation with $p=0.002, \alpha=0.05$. It showed that task delegation from the chief nurse was effective to improve nurse's job satisfaction. It is in line with research conducted by Habe (2008) which concluded that authority delegation positively influences the personnel or in this case nurse's work efficacy.

\section{CONCLUSION}

This quantitative study successfully answers the context of the study about the implementation of 'Relactor' Nursing Delegation Model (MDK'R') in terms of responsibility, authority, and accountability with a good and optimum score. Even though the authority component only gains a less optimum good score. Therefore, an explanation is needed to solve the problem. The implementation of the nursing delegation needs a suitable procedure, such as delegation acceptor, delegation conveying, delegation time allotment, and delegation planning in a qualitative study. The implementation of nursing delegation can be successful with the support from the management team by establishing regulation and policy about the delegation. The regulation and policy may be in a form of the standard of operational procedure or SOP, document and form about the implementation of the delegation, and the other legal document which protects the delegation acceptor legally.

The recommendation for this research is the refreshment program and $M D K^{\prime} R^{\prime}$ 'evaluation related to the task delegation and the motivation to complete the delegated task using 'Relactor' model.

\section{ACKNOWLEDGEMENT}

The researcher would like to say thank you for the Ministry of Research, Technology, and Higher Education of Indonesia for the research funding support and LPPM UNIMUS for the given facility during the research. Also, for the participants who agreed to give the information needed for the research. A huge gratitude for family and friends for the endless support given towards me as a researcher.

\section{REFERENCES}

Habe, H. (2008). Pengaruh Pendelegasian Wewenang dalam Meningkatkan Efektifitas Kerja Karyawan pada PT Telekomunikasi Ludonesia (Persero) Cabang Lampung. Journal sains dan Inovasi, 6(2), pp 127-133.

Hidayat, A., Hariyati, T. and Muhaerawati, T. (2019). Analisis Fungsi Manajemen Kepala Ruangan dalam Pendelegasian kepada Ketua Tim di Unit Rawat Jalan Rumah Sakit Militer Jakarta: Fishbone Diagram. Journal Penelitian Kesehatan Suara Forikes, 10(2), pp 99-104.

Kærnested, B. \& Bragadóttir, H. (2012). Delegation of Registered Nurses Revisited: Attitudes towards Delegation and Preparedness to Delegate Effectively. Nordic Journal of Nusring Research Vard INorden, 32(1), pp 10-15.

Marquis, B. \& Huston, C. (2012). Kepemimpinan dan Manajemen Keperawatan: Teori dan Aplikasi. $4^{\text {th }}$ edition Jakarta: Penerbit Buku Kedokteran EGC. 
Monteiro, E. \& Simbolon, S. (2014). Pola Penggunaan Waktu Kepala Ruang Untuk Menjalankan Fungsi Manajemen di Ruang Rawat Inap Rumah Sakit Sumber Waras Jakarta Barat. Nursing Current Journal, 2(1), pp 1-10.

Ovari, I., Setyowati, S. \& Yasmi, Y. (2017). Pendelegasian Tugas Kepala Ruangan Menurut Persepsi Perawat Pelaksana dapat Meningkatkan Kepuasan Kerja', Jurnal Ipteks Terapan. Research of Applied Science and Education, VII(13), pp 194-207.

Parmin, P. (2010). Hubungan Pelaksanaan Fungsi Manajemen Kepala Ruangan dengan Motivasi Perawat Pelaksana di Ruang Rawat Inap RSUP Undata Palu. Universitas Indonesia.

Pohan, V.Y. (2016). Development and Application of "Relactor" Nursing Delegation in Modeling Indonesia. Journal of Nursing Management, 1(1), pp 3-5.

Pohan, V.Y. (2017). Efektifitas Model Delegasi Keperawatan 'Relactor' terhadap Kualitas Pendelegasian Keperawatan di Rumah Sakit Roemani Semarang. Universitas Indonesia, Indonesia.

Prawesti, A. Emaliyawati, E., Trisyani, Y. \& Adimiharja (2017). Peningkatan Kompetensi Perawat Puskesmas Dalam Penanganan Tanggap Darurat Kasus Henti Jantung Sebagai Upaya Menurunkan Angka Mortalitas. Journal Pengabdian Masyarakat, 1(5), pp 325-328.

Raodhah, S., Nildawati \& Rezky (2017). Hubungan Peran Kepala Ruangan Dengan Kinerja Perawat Di Ruang Rawat Inap Rsud Syekh Yusuf Kabupaten Gowa. Al-Sihah Public Health Journal, 9(1), pp 94-102.

Risal (2015). Hubungan antara Pengetahuan dan Sikap Perawat tentang Pendelegasian dengan Mutu Perilaku Perawat dalam Pendelegasian di RSI Aisyiyah Malang. University of Muhammadiyah Malang, Indonesia.

Swansburg, R. (2009). Pengantar Kepemimpinan dan manajemen Keperawatan untuk Perawat Klinis. Jakarta: Penerbit Buku Kedokteran EGC.

Tampubolon, B. (2004). Fungsi pendelegasian tugas dan wewenang dilakukan pada PT Dwikarya Mudasena Batam. Universiti of HKBP Nommensen. Retrieved from: https://akademik.uhn.ac.id/portal/public_html/JURNAL/ TULISAN BANTU TAMPUBOLON/ANALISIS PENDELEGASIAN TUGAS DAN WEWENANG.pdf.

Wahyuningsih, A. \& Yusiana, M. (2016). Persepsi Perawat tentang Pendelegasian Tugas Kepala Ruang Mempengaruhi Tingkat Kepuasan Kerja Perawat. Journal Stikes RS Baptis Kediri, 9(2).

Zulkarnain, Z. (2017). Analisis Pelaksanaan Fungsi Manajemen Pengarahan Kepala Ruangan Dengan Kinerja Perawat Dalam Menerapakan Asuhan Keperawatan Di Ruang Rawat Inap RSUD Bima. Jurnal Ilmu Sosial dan Pendidikan, 1(2), pp 229-255. 